\title{
Fatwaer og forandringer: Islamisk lovpraksis i Vesten ${ }^{i}$
}

\author{
Af ph.d. Karen-Lise Johansen Karman
}

Må muslimer i Vesten spise ikke-halal slagtet kød? Må en muslimsk kvinde gifte sig med en ikke-muslimsk mand? Må muslimer i Europa stemme ved politiske valg? Sådan lyder nogle af de spørgsmål, som det europæiske fatwaråd The European Council for Fatwa and Research (ECFR) gennem tiden har modtaget fra muslimer bosat i Vesten og besvaret i form af religiøse anvisninger (fatwaer). Denne artikel ser nærmere på ECFR og dets fatwaer og viser, hvordan The European Council for Fatwa and Research opfordrer til integration samtidig med, at det viser vejen for en øget institutionalisering af islam gennem blandt andet etablering af islamiske voldgiftsdomstole i Europa.

Siden den tidlige islam har grupper af muslimer levet i områder, hvor størstedelen af befolkningen var ikke-muslimer. Konfrontationen med ikke-muslimers levevis førte løbende til overvejelser blandt de muslimske minoriteter om, hvordan islam skulle praktiseres og resulterede i en øget efterspørgsel efter fatwaer om udførelsen af islamisk praksis i et ikke-muslimsk samfund (Shadid and Koningsveld 1996:84-114). Spørgsmålene fra muslimer uden for den muslimske majoritetsverden affødte tidligt en diskussion blandt muslimske retslærde om muslimske minoriteters status og religiøse forpligtigelser. Nogle muftier erklærede, at alle aspekter af Sharî'a gælder for alle muslimer, uanset hvor de bor. Andre fastslog, at det er nødvendigt at tage højde for lokal praksis og tilpasse praktiseringen af islamisk lov. Andre igen afviste helt, at det er muligt at praktisere islam blandt ikke-muslimer (Abou El Fadl 1994:141-187). I hanafistiske lovdoktriner samlet af al-Shaybânî (d.804) fastslås det eksempelvis, at ikke alle aspekter af den islamiske lov nødvendigvis skal praktiseres i ikke-muslimske samfund, og handlinger, som er forbudte i islam, tillades, så længe de er lovlige i forhold til ikke-muslimsk lovgivning, fx handel med alkohol og svinekød (al-Shaybânî 1971 ed.: vol.4, 486-90). Hvorimod den indflydelsesrige maliki retslærd, al-Wansharîsî (d.1508), i fatwaer efter Granadas fald i 1492 hævder, at korrekt udførelse af bøn ikke er muligt på grund af en rituel forurening fra kristne (Harvey 1990:58). Disse forskelle illustrerer, hvordan retslærdes krav til muslimske minoriteter blev formet af dynamiske juridiske debatter, som var præget af muslimernes sociale forhold. De retslærde udledte ikke udelukkende vejledning ud fra lovskolernes teoretiske udgangspunkt, men interagerede og forholdt sig til modtagernes sociale forhold, og fatwaerne blev af mange muftier anvendt som et instrument til at respondere på sociale ændringer (Johansen 1993:29-47, Skovgaard-Petersen 1997:4). 


\section{The European Council for Fatwa and Research}

I dag er antallet af muslimer bosat i lande med ikke-muslimsk majoritetsbefolkning det hidtil største i islams historie, og spørgsmålet om muslimske minoriteters pligter har gradvis fået fornyet relevans. Som konsekvens af dette er antallet af fatwaråd i Vesten, som blandt andet har til formål at afklare eventuelle konflikter mellem vestlig lovgivning og islamiske regler, tilsvarende øget. Fatwarådene søger praktiske løsninger, som gør det muligt for muslimer at navigere i den ikke-muslimske kontekst uden at gå på kompromis med religiøs identitet og praksis (DeLorenzo 2000:69). Et af disse fatwaråd er The European Council for Fatwa and Research (ECFR), som på en række punkter adskiller sig fra mange af de andre vestlige råd. Forskelligt fra størstedelen af de vestlige fatwainstitutioner er ECFR ikke lokalt forankret i ét bestemt nationalt miljø eller tilknyttet ét uddannelsesinstitut eller én moské, men er derimod institutionelt uafhængigt og supernationalt i den forstand, at det henvender sig til muslimer i hele Europa og tæller medlemmer med forskellige nationale baggrunde. Den følgende præsentation af The European Council for Fatwa and Research vil fokusere på fatwarådets institutionelle forhold og diskutere, hvordan disse samt den sociale praksis, det opererer i, influerer på dets beslutninger.

\section{Baggrund for rådets oprettelse}

Waiting to form the first scholars, we have not spared efforts to form the European Council for Fatwa and Research, gathering distinguished scholars and erudite scientific specialist, known for their piety and knowledgeable of the European reality. These scholars have the mission of orienting and counseling European Muslims: how should they behave daily with their cocitizens, at the individual, collective, or institutional levels, in the field of politics, society and economics. ${ }^{i i}$

Med disse ord valgte Ahmad al-Râwî, den tidligere formand for Federation of Islamic Organisations in Europe - FIOE (Sammenslutningen af Islamiske Organisationer i Europa), at beskrive ECFR i sin åbningstale ved rådets stiftende møde i 1997. Beskrivelsen afspejler meget præcist tankerne bag og formålet med fatwarådet. FIOE, som repræsenterer europæiske bevægelser relateret til Det Muslimske Broderskab (Maréchal 2008:36), var initiativtager til fatwarådet, og det er ikke overraskende, at FIOE tog initiativ til at etablere et sådant råd. FIOE's målsætning er at fremme islamisk levevis og islamiske

(C) Forfatteren og Tidsskrift for Islamforskning, ISSN 1901-9580, publiceret 15-02-2010 
normer i Europa, og gennem etableringen af et fatwaråd, som kan udstikke religiøse anvisninger om korrekt islamisk praksis i Europa, kan dette projekt promoveres. Udover at et europæisk fatwaråd kan støtte FIOE's projekt om at styrke islamiske principper blandt muslimer i Vesten, var der også andre forhold, som motiverede til oprettelsen af rådet (Caeiro 2004). En særlig væsentlig årsag til etableringen var, ifølge FIOE, det store behov for en autoritet i Europa, som på kvalificeret vis kunne vejlede og give religiøse anvisninger til muslimer i Vesten. Den manglende religiøse autoritet medførte, ifølge FIOE, at muslimer i Vesteuropa var i fare for at blive oversvømmet af fatwaer med modsatrettet indhold udstedt af muftier med begrænset indsigt i de vesteuropæiske forhold. ${ }^{i i i}$ Eftersom FIOE forventede, at det ville tage en årrække, før muslimske autoriteter født og/eller opvokset i Europa var uddannet og klar til at løfte denne opgave, var hensigten med ECFR, at det skulle fungere som en midlertidig institution af respekterede lærde, der i en mellemliggende periode kunne vejlede europæiske muslimer, indtil en ny generation af europæiske lærde var uddannet. ${ }^{\text {iv }}$

Et andet motiv bag oprettelsen af rådet var ønsket om at bekæmpe, hvad FIOE oplevede som en mangel på konsensus og enighed blandt muslimske lærde bosat i Vesteuropa. FIOE var bekymret for, at det manglende samarbejde blandt lærde ville føre til en splittelse blandt muslimer og modstridende opfattelser af, hvordan man som muslim i Vesten kan efterleve islam. Formålet med ECFR er dermed dels, som det er formuleret $\mathrm{i}$ rådets vedtægter, "at regulere muslimers interaktion med de europæiske samfund inden for Sharî‘'a's regler og mål”, dels at skabe samarbejde blandt lærde omkring udledning af islamiske retningslinjer for muslimer i Vesten. ${ }^{\mathrm{v}}$

\section{ECFR's medlemskab - en øget arabisering}

FIOE udvalgte rådets første 25 medlemmer, hvoraf fem boede uden for Europa, heriblandt rådets præsident Yûsuf al-Qaradâwî. Tanken var, at rådets udenlandske medlemmer gradvis skulle erstattes af europæiske lærde, men udviklingen tog en anden retning, og i stedet er der langsomt sket en arabisering af rådet. I dag har rådet 34 medlemmer, 14 bor uden for Europa og størstedelen af dem i Mellemøsten. Derudover er antallet af medlemmer fra Europa med en arabisk baggrund steget, hvilket har haft konsekvenser for rå- 
dets fatwaproduktion og dens udbredelse. ECFR havde til hensigt at udgive materiale på forskellige europæiske sprog, men har indtil videre kun udgivet materiale på arabisk foruden en engelsk oversættelse af rådets første fatwasamling. En overvejende produktion af arabiske tekster sætter begrænsninger for hvilke miljøer, ECFR når ud til. Målsætningen var at blive en autoritet for alle muslimer i Europa uanset etnicitet, men fatwarådet har primært formået at gøre sig kendt i arabisktalende miljøer og refereres sjældent til i tyrkiske eller urdu-talende miljøer. ${ }^{\text {vi }}$ Internt i ECFR er der uenighed om, hvorvidt udenlandske lærde bidrager positivt til rådets arbejde eller ej. Nogle medlemmer beklager, at det europceiske råd er blevet arabisk, mens andre vurderer, at anerkendte lærde fra Mellemøsten styrker rådets legitimitet og autoritet blandt muslimer i Vesten. ${ }^{\text {vii }}$ Der er forskellige forklaringer på det stigende antal udenlandske medlemmer. Inddragelsen kan have været et forsøg på at reducere kritikken af ECFR rettet af islamiske lærde fra klassiske læreinstitutter og fatwaråd i den muslimske verden (Caeiro 2003:26-27), men kan også have været et forsøg på at signalere, at ECFR's fatwaer kan have relevans uden for Europa. Nogle af ECFR's fatwaer er uden referencer til den europæiske kontekst, og umiddelbart virker det som om, at de retter sig til et bredere publikum af modtagere, der ikke nødvendigvis er bosat i Vesten.

\section{At vare et fatwaråd $i$ Vesten}

Den sociale praksis, som The European Council for Fatwa and Research og andre vestlige fatwaråd opererer $i$, afviger på centrale punkter fra den praksis, som langt hovedparten af fatwaråd i den muslimske verden virker i. For det første er ECFR placeret i et flerkulturelt miljø, som involverer muslimer med forskellige nationale baggrunde. Denne diversitet i det muslimske minoritetssamfund indebærer, at der er mindre religiøs konsensus blandt muslimer i Vesten sammenlignet med et mere homogent muslimsk majoritetssamfund. Dette giver mulighed for at diskutere emner, som traditionelt set ikke berøres i den muslimske verden såsom behovet for at skelne mellem tro og kulturel praksis i forbindelse med eksempelvis klædedragt og forholdet mellem kønnene (Esposito 2002:253). Dernæst er det karakteristisk for de vestlige råd, at de ikke er underlagt en politisk styring, men fungerer uafhængigt af statslige myndigheder. Flere medlemmer hævder, at rådets

politiske og institutionelle uafhængighed ikke nødvendigvis har påvirket deres holdnin- 
ger, men givet muligheder for at proklamere synspunkter, som afviger fra konsensus blandt lærde eller politiske autoriteters holdninger. ${ }^{\text {viii }}$ Sidstnævnte påstand er en indirekte kritik af en af sunniislams vigtigste institutioner for islamisk tænkning, nemlig al-Azhar universitetet i Kairo, som mange mener er underlagt politisk kontrol og kun udsteder politisk godkendte anvisninger.

Studier af ECFR's forskningsemner og fatwaer viser imidlertid, at det kun sjældent fordyber sig i emner, der betragtes som kontroversielle i den muslimske verden. Dette eksemplificeres ved den kendsgerning, at ECFR's mere omdiskuterede beslutninger, som tilladelsen af at finansiere boligkøb med traditionelle banklån (ribâ), hvor der betales renter, og accepten af at kvinder undlader at bære tørklæde under særlige omstændigheder, tidligere har været behandlet af blandt andre lærde fra al-Azhar (Karman 2007:84). Af og til beskæftiger de vestlige råd sig med emner, som der ikke er tradition for at diskutere i den muslimske verden, men årsagen til, at de ikke tidligere har været omdrejningspunkt for diskussion har ikke været emnernes kontroversielle karakter, men snarere at disse emner simpelt hen ikke har været relevante at diskutere i et muslimsk majoritetssamfund.

Mens nogle af rådsmedlemmerne fremhæver det frie intellektuelle miljø i Vesten, oplever andre, at denne frihed er indskrænket efter 11. september 2001 og i særdeleshed efter bombesprængningerne i London 7. juli 2005. Rådsmedlem og sekretær for Sharî‘a rådet i London, Suhayb Hassan, udtaler, at der efterhånden kun er plads til en "vestlig, liberal islamfortolkning i Europa", og at imamer med en anden tilgang til islam er blevet påpasselige med at ytre deres holdninger offentligt og er i stedet begyndte at censurere deres khutbaer. De medlemmer, som derimod fremhæver friheden i Vesten, er ofte personer med tilknytning til Muslimsk Broderskabsforeninger og lignende organisationer, der samarbejder med vestlige regeringer og spiller en dynamisk rolle i den offentlige debat om muslimers interesser i Vesten, og som har en større frihed i Europa end tilfældet er for lignende organisationer i Mellemøsten. 


\section{Det Muslimske Broderskab i nye forkladninger?}

ECFR er ofte blevet karakteriseret som en repræsentant for Det Muslimske Broderskab i Vesteuropa, både pga. dets tætte relationer til FIOE, og fordi centrale medlemmer, heriblandt præsidenten al-Qaradâwî har relationer til Det Muslimske Broderskab i Mellemøsten. Interviews med medlemmerne viser imidlertid, at der er stor ideologisk diversitet blandt rådets medlemmer. En gruppe af medlemmer er forholdsvis traditionelle og i høj grad præget af den islamtilgang, som er gældende i både deres oprindelsesland og blandt den etniske gruppe, som de repræsenterer i Europa. Frem for at fokusere på spørgsmålet om tilpasningen af islam til Vesten, ønsker de at bevare etniske og kulturelle traditioner som legitime udtryk for islamisk praksis og arbejder for at skabe plads for lokale vaner og traditionelle livsmønstre i et ikke-muslimsk samfund. En anden gruppe medlemmer kan beskrives som salafistiske. Nogle fra denne gruppe har studeret i Saudi Arabien, og de er stærkt kritiske over for flere af ECFR's fatwaer, som disse medlemmer vurderer i alt for stor udstrækning går på kompromis med islam i et forsøg på at tilpasse den islamiske praksis til den lokale kontekst. Deres målsætning er, at muslimer i Vesten efterlever alle islamiske principper og pligter og følger Profetens eksempel uden at lade sig begrænse af de vestlige forhold. Denne gruppe af medlemmer mener ikke, at ECFR skal bidrage til at styrke muslimers indflydelse i Europa gennem politisk engagement, men anbefaler i stedet, at muslimerne isolerer sig og ikke lader sig præge af vestlige principper. Der har været en del kontroverser omkring denne gruppe i rådet, og enkelte af disse salafistiskinspirerede medlemmer har trukket sig for senere at vende tilbage til ECFR pga. uenighed om den linje, fatwarådet har lagt i dets religiøse anvisninger. Dermed er det også sagt, at den mest dominerende position i rådet, er den langt mere pragmatiske og fleksible, når det kommer til tilpasningen af islamisk praksis. Medlemmerne af denne gruppe kan kategoriseres som islamistiske, hvoraf nogle har/har haft tilknytning til politiske bevægelser i Mellemøsten, eksempelvis Det Muslimske Broderskab. Som det er karakteristisk for islamismen, insisterer denne gruppe af medlemmer på, at fortolkningen af islam og efterlevelsen af islam kontekstualiseres. De understreger, at islam uproblematisk kan efterleves uanset samfundstype og forholdsvis let kan tilpasses specifikke kontekster, også selv om disse er præget af en ikke-muslimsk majoritetsbefolkning. Denne gruppe af rådsmedlemmerne opfordrer de europæiske muslimer til at organisere sig og involvere sig i politi- 
ske debatter for derigennem at skabe plads til den muslimske identitet og påvirke samfundet med muslimske værdier.

Denne ideologiske diversitet internt i rådet har til tider hæmmet rådets kreativitet, da det som udgangspunkt ønsker at træffe beslutninger og udstede religiøse anvisninger ved enstemmighed. Den tilbagevendende uenighed har gradvist medført visse ændringer i rådets arbejdsmetode. I starten fokuserede ECFR på at besvare spørgsmål og udstede fatwaer, men begyndte efterhånden at lægge flere kræfter i studier af forskellige aspekter af islamisk lov med det formål at nå frem til et fælles grundlag, hvorudfra kollektive beslutninger kan træffes. Enkelte spørgsmål har det taget ECFR flere år at besvare, da besvarelsen forudsatte grundige studier af den islamiske retsvidenskab på grund af stor uenighed blandt rådsmedlemmerne. Denne arbejdsmetode har paradoksalt nok resulteret $i$, at rådet sommetider har udstedt ret utraditionelle fatwaer. Ved udviklingen af eksempelvis fatwaen, som tillader ægteskab mellem en kvindelig muslimsk konvertit og ikke-muslimsk mand, opnåede ECFR konsensus for en fleksibel fortolkning på baggrund af rådets mere pragmatiske tænkeres tilsyneladende overbevisende argumentation. Denne fatwa fremstår som rådets kollektive beslutning, men de salafistiske medlemmer kritiserer fatwaen for at være baseret på svage hadither og historiske fatwaer, som ikke er optaget i anerkendte fatwasamlinger. ${ }^{\text {ix }}$

ECFR har indtil videre udgivet én fatwasamling bestående af 80 fatwaer opdelt efter forskellige underemner som bøn, arbejde og økonomiske forhold, ægteskab og skilsmisse, spiseregler m.m. Derudover udgiver ECFR i forlængelse af dets årlige møder en publikation, der bl.a. gengiver et udvalg af de fatwaer, som rådet har truffet beslutning om. I det følgende vil en række af ECFR's fatwaer blive diskuteret med en særlig fokus på religiøse anvisninger, som illustrerer, hvordan ECFR vejleder muslimer til at navigere i et ikkemuslimsk samfund med respekt for såvel islamiske retsprincipper som demokratiske principper i Vesten. 


\section{Fatwaer om sharî́a domstole, demokratisk deltagelse og medborgerskab}

Studier af rådets fatwaer viser, at det med sine religiøse anvisninger har som formål at fremme religiøs praksis og institutionalisering af islam gennem en fortolkningsmetode, der tager udgangspunkt $i$, at det ikke skal være besværligt at være praktiserende muslim, og at udøvelsen af de islamiske principper skal tilpasses den lokale kontekst. Dette synspunkt kommer eksempelvis til udtryk $\mathrm{i}$ en fatwa om muslimske begravelsespladser. ECFR opfordrer muslimer til at etablere muslimske begravelsespladser som led $\mathrm{i}$ at synliggøre muslimers tilstedeværelse i Europa, men hvis dette ikke er muligt, er det tilladt at begrave muslimer i et særligt område på en kirkegård. Desuden tilføjer fatwaen, at hvis ingen af disse muligheder er til stede, må en muslim gerne begraves på en kristen begravelsesplads, da "gud ikke ønsker at pålægge den praktiserende muslim unødvendige byrder". En tilsvarende pragmatisme ses i en fatwa vedrørende muslimske kvinders pligt til at bære tørklæde (hidjâb). Fatwaen tilskynder i høj grad muslimske kvinder i Vesten til at gå med tørklæde, eftersom ECFR fastholder, at det er en religiøs pligt og syndigt at gå uden. Samtidig tillader rådet, at muslimske kvindelige konvertitter undlader at bære tørklæde, hvis det volder dem for meget besvær i forhold til den ikke-muslimske familie. ${ }^{\text {i }}$

\section{Islamiske voldgiftsdomstole}

Ønsket om at styrke institutionaliseringen af islam afspejles i mange af ECFR's fatwaer, men er særligt tydeligt i en række overordnede anbefalinger, som fatwarådet løbende har formuleret. I disse anbefalinger opfordres muslimer i Vesten blandt andet til at opdrage deres børn i "islamiske miljøer" ved at oprette "islamiske skoler, uddannelsesinstitutioner og fritidsklubber" xii Muslimer i Europa anbefales at oprette islamiske banker og lignende finansielle institutioner, som følger principperne for islamisk økonomi. Desuden anbefales det, at moskéer efterstræber sig på at blive officielt godkendte og få officiel vielsesbemyndigelse af de vestlige myndigheder. Sidst men ikke mindst opfordres muslimer i Vesten til at oprette islamiske voldgiftsdomstole, som har autoritet til at træffe juridisk bindende beslutninger inden for civilretslige anliggender. ${ }^{\text {xii }}$ ECFR er af den klare opfattelse, at de muslimske samfund i Europa ikke har nogen muligheder for at realisere implementering af islamisk lovgivning som et generelt system i Europa, der erstatter de nationale sekulære retssystemer. Et sådant fremtidsscenario debatteres ikke i rådets religiø- 
se anvisninger og er en forestilling, som i interviewene med medlemmer bliver affejet som et hypotetisk og irrelevant spørgsmål. Derimod er målet at skabe bedst mulige rammer for religiøs praksis for muslimer i et sekulært land, og som middel til dette mener ECFR, at det er legitimt at arbejde for implementering af Sharî‘a inden for blandt andet familiesager gennem etablering af voldgiftsdomstole. I en anbefaling fra 2002, understreger ECFR, at muslimer i Europa bør søge voldgiftsmægling, der følger islamisk lov især i forbindelse med personlige og finansielle anliggender. Argumenterne for dette er blandt andet, at gennem islamisk mægling kan muslimer langt hurtigere få afgjort deres indbyrdes sager og konflikter samtidig med, at de undgår at overbebyrde de officielle domstole. ${ }^{\text {xiv }}$ Med denne argumentation forsøger ECFR at signalere, at rådet viser anerkendelse og respekt for verdslige domstole ved ikke at ville belemre dem med sager af en art, der kan løses på anden vis. I september 2008 fik et britisk netværk af fem islamiske voldgiftsdomstole juridisk magt til at træffe bindende afgørelser i civilretslige søgsmål, men forud for dette og fortsat i dag eksisterer mange andre uofficielle islamiske domstole. En af disse er Islamic Sharî́a Council i London, hvor fatwarådsmedlem Suhayb Hassan er generelsekretær. Ifølge ham blander Islamic Sharî‘ a Council sig ikke i det officielle retssystems beslutninger, men sikrer gennem mægling, at muslimske familieforhold er arrangeret i henhold til islamiske principper, eksempelvis i forbindelse med indgåelse af ægteskabskontrakter.

Tanken om at implementere juridiske elementer af Sharî‘a i Europa afleder ofte udtryk for bekymring om, hvorvidt dette på sigt vil betyde, at fysisk afstraffelse som stening og amputationer bliver en del af det europæiske retssystem. Officielt skal applicering af islamiske lovprincipper følge europæisk lov, og hvis en voldgiftsdomstols beslutning er i strid med et lands konstitutionelle borgerrettigheder, kan beslutningen ikke stadfæstes (Rohe 2007:139). Et stort antal af islamiske lovprincipper er ikke i modstrid med de ovennævnte standarder og kan forholdsvist uproblematisk efterleves i Europa inden for rammer af europæiske standarder for menneskerettigheder og retsstatsprincipper. Men, som det ligeledes fremgår af ovenstående, eksisterer der en række uofficielle Sharî‘aråd, som i et vist omfang bistår i reguleringen af familieretslige forhold ifølge islamiske nor- 
mer, og denne regulering er svær at kontrollere, da den foregår uden det officielle systems kendskab.

På trods af, at ECFR i sine anbefalinger fastslår, at muslimer er forpligtede til at følge de europæiske landes lovgivning, har det i flere tilfælde udstedt fatwaer, som ikke tager hensyn til eller er i direkte modstrid med vestlig lovgivning (Karman 2009:100). ECFR har for eksempel modtaget et spørgsmål om reglerne vedrørende ægteskab med mere end én kvinde. Som svar udstedte ECFR en længere fatwa, der i detaljer beskriver accepten af polygami inden for islam. ${ }^{\mathrm{xv}}$ Fatwaen afslutter med at anbefale polygami og tager på ingen måde højde for vestlig lovgivnings forbud mod polygamiske ægteskaber. Dette eksempel er dog langt fra ensbetydende med, at ECFR generelt vejleder kønsdiskriminerende. Når det handler om forholdet mellem kønnene, vejleder ECFR som regel til fordel for kvinden og søger med sin vejledning at bryde kulturelle mønstre for kønsdiskriminerede traditioner (Caiero 2003). ECFR har udstedt en fatwa, hvori det fraråder en nygift mand, som har fundet ud af, at sin kone ikke er jomfru, fra at søge skilsmisse af hensyn til kvinden. Derudover har det gentagende gange understreget, at kvinder har ret til at deltage i fredagsbøn og øvrige aktiviteter i moskéen og opfordrer moskébestyrelser til at skabe velegnede fysiske rammer for kvinder. ${ }^{\text {xvi }}$

Rådets ignorering af vestlig lovgivning er ikke nødvendigvis udtryk for, at medlemmerne har en begrænset indsigt $\mathrm{i}$ vestlige forhold. Forklaringen er snarere, at ECFR med disse fatwaer bevidst adresserer grupper af muslimer i Europa, som lever i fuldstændig overensstemmelse med Sharî‘a uden hensynstagen til vestlig lovgivning. ECFR har nemlig med sine religiøse svar en tendens til at imødekomme spørgernes ønsker eller spørgernes måde at handle på, som de kommer til udtryk i spørgsmålet. Dette er både tilfældet, når det gælder meget ortodokse spørgere, men også når spørgsmålet drejer sig om nye handlingsmønstre affødt af vestlige forhold. Fatwaernes rolle er i mange tilfælde ikke at udstikke retningslinjer for, hvordan muslimer skal handle, men i stedet at legalisere og blåstemple allerede udbredte måde at handle på, i fald de ikke er i strid med islamiske principper (Hussain 2004:378). 


\section{Politisk deltagelse - en national pligt}

ECFR's opfordring til etablering af islamiske voldgiftsdomstole er ikke et udtryk for, at det anbefaler muslimer at isolere sig fra det ikke-muslimske samfund eller oprette parallelle samfund med begrænset kontakt til ikke-muslimer. Tværtimod er det ECFR meget på sinde, at muslimer engagerer sig i samfundsmæssige forhold, deltager i offentlige debatter og forsøger på forskellig vis at bruge deres legitime ret som samfundsborgere til at gøre deres indflydelse gældende. Vigtigheden af samarbejde og engagement er også skrevet ind i ECFR's formålsbeskrivelse, hvor det er præciseret, at det skal gøre "store anstrengelser" for at involvere sig med offentlige myndigheder i europæiske lande og blive anerkendt og anvendt som vejledende organ i emner vedrørende den muslimske befolkning i Vesteuropa. Rådet har til hensigt at viderebringe budskabet om, at en tilværelse som aktiv muslim er foreneligt med vestlige forhold gennem oplysning og vejledning til muslimer, men også til ikke-muslimske offentlige institutioner. På ECFR's årlige møde i 2006 konkluderede det med henvisning til en beslutning fra den islamiske konferenceorganisation, at det er tilladt at bidrage til sociale, politiske og økonomiske aktiviteter i ikke-muslimske lande, så længe disse aktiviteter ikke er i modstrid med islamisk moral, praksis og læresætninger. ${ }^{\text {xvi }}$

På det principielle niveau går denne grænse for engagement igen i mange af ECFR's fatwaer, men for ikke at komplicere livet som muslim i Vesten accepterer ECFR ofte en tilsidesættelse af islamisk praksis. En ung mand stiller for eksempel spørgsmålet, om det er tilladt at arbejde på McDonalds, hvilket indebærer salg af svinekød, som er i strid med traditionel islamisk praksis om, at hvad der er forbudt at indtage - fx alkohol og svinekød - også er forbudt at sælge. ECFR svarer, at den profetiske sunna foreskriver, at salg af svinekød er forbudt, og derfor bør manden straks finde et nyt job. Fatwaen tilføjer dog, at hvis manden ikke har mulighed for at finde et job, der kan give en tilstrækkelig indkomst, må han fortsætte med at arbejde hos McDonalds. ${ }^{\text {xviii }}$ Af hensyn til den unge mands levevilkår, tillader ECFR på denne måde økonomiske aktiviteter, der er i modstrid med almindelig islamisk praksis. 
Fatwarådet har et par gange modtaget spørgsmål om politisk deltagelse i et sekulært, ikke-muslimsk politisk system. Første gang spørgsmålet blev stillet var i 1998 - året efter rådets oprettelse - og på daværende tidspunkt tøvede ECFR med at udstede en entydig fatwa på dette område. I stedet lød svaret på spørgsmålet, at politisk deltagelse var et kontekstafhængigt anliggende, som ECFR ikke kunne udstede generelle retningslinjer for. Argumentationen var, at hvis muslimernes interesse udelukkende kunne varetages gennem politisk deltagelse, så var deltagelsen acceptabel, men kun lokale autoriteter kunne vurdere, om politisk deltagelse tjente dette mål. ${ }^{\text {xix }}$ Svaret kan tolkes således, at grundlæggende mente ECFR, at politisk deltagelse i Vesten var i modstrid med islamisk praksis, men såfremt deltagelse var til gavn for muslimer, var det acceptabelt at gå på kompromis med islamiske retslige normer vedrørende politisk engagement.

I april 2007, blev endnu en fatwa om politisk deltagelse udstedt af ECFR offentliggjort på hjemmesiden "islamonline". Spørgsmålet lød,

Is it permissible for Muslims living in non-Muslim countries to take part in elections held in those countries? Keeping in mind that such elections may make Muslims [be]come members of the legislative organs in countries where there is not any consideration for the Sharî‘ a?

ECFR udstedte en længere fatwa og svarede blandt andet,

Thus, Muslims' participation in elections is a national duty. [...] Besides, it is a kind of mutual cooperation with those whom Muslims think is potential candidates who, if they win the elections, will bring benefits for the society in general and Muslims in particular.

I 1998 kunne ECFR ikke afgøre om politisk deltagelse var tilladt, men knap ti år senere, fastslår det, at deltagelse er en borgerpligt. En af forklaringer på denne udvikling i ECFR's måde at vejlede på er, at fatwarådet gradvis er blevet mere bevidst om, hvilken rolle det bør spille for de muslimske miljøer i takt med, at den muslimske befolkningsgruppe i Vesten bliver mere talrig. Derudover har ECFR i de ti år, der er gået fra rådet fik sit første spørgsmål om politisk deltagelse til det andet, fået mere erfaring $\mathrm{i}$ at forholde sig til muslimers forhold i Vesten. Samtidigt har ECFR udarbejdet adskillige teologiske analyser om muslimske minoriteter baseret på utallige interne debatter og oplever for- 
mentlig, at det som en kollektiv stemme efterhånden har et mere solidt og fælles fundament at basere sine konklusioner og anvisninger på.

Argumentationen i svaret fra 2007 minder om de argumenter, der blev fremsat i ECFR's første fatwa om emnet tilbage i 1998. Deltagelse er tilladt, eftersom valget af den rigtige kandidat, udover at bidrage med noget positivt til samfundet, kan være gavnligt for muslimer. Fatwaen fra 2007 adskiller sig dog fra den første ved at indeholde mange religiøse referencer og teologiske beviser til støtte for svaret. Blandt andet refereres der til hadîther, som beskriver, hvordan Profeten Muhammad indgik kontakter med ikke-muslimer til gavn for samfundet. Dette overføres til samtiden, og det argumenteres, at ligesom Profeten interagerede i kontraktforhold til ikke-muslimer, er det i dag tilladt for muslimer at engagere sig politisk med ikke-muslimer for at fremme egne interesser som religiøs minoritet, men også for at bidrage - tilsvarende Profeten - til en positiv samfundsudvikling.

Endvidere bliver formålet med den politiske deltagelse detaljeret beskrevet i en anvisning fra 2006, hvor det forklares, at målet med et politisk bidrag er at "bevare rettigheder og frihed, forsvare moralske og spirituelle værdier, beskytte en muslimsk tilværelse i ikkemuslimske lande samt fremme muslimernes juridiske interesser". ${ }^{\mathrm{xx}}$ Opfordringer for det politiske engagement er dermed ikke nødvendigvis baseret på en udtalt begejstring for det sekulære demokrati i Vesten og et stærkt ønske om at støtte og videreudvikle systemet, men baseret på en anerkendelse af, at kun ved at bakke op om det politiske system og deltage aktivt er det muligt at tjene muslimers interesse og opnå indflydelse på lige fod med andre europæiske borgere. ECFR vejleder imamer i Vesten til at opfordre muslimer til politisk deltagelse, men har alligevel nogle kritiske forbehold for visse aspekter af det vestlige politiske styre, hvilket kommer til udtryk i anvisningen fra 2006, hvor ECFR referer til et citat fra sura (5:2), som lyder "Hjælp hinanden i fromhed og gudsfrygt, ikke i synd og fjendskab!" ${ }^{x x i}$ ECFR har således den opfattelse, at muslimer i Vesten som medborgere er forpligtiget til politisk deltagelse, såfremt denne deltagelse ikke fører til handlinger og beslutninger, der truer den muslimske identitet, og som strider imod muslimers religiøse værdier og moralske principper. Principper ECFR beskriver som "sandfærdighed, retfærdighed, ærlighed, respekt for diversitet og afstandstagen fra vold". xxii 


\section{Muslim og medborger}

Netop spørgsmålet om medborgerskab og integration har optaget ECFR en del, og de årlige møder i henholdsvis 2006 og 2007 var alene afsat til diskussion om dette emne. Dette vidner om dynamikken i ECFR's arbejde, der rent faktisk forholder sig til de debatter og diskussioner, der er aktuelle for muslimer i Vesten. I diskussionen vedrørende medborgerskab tager ECFR udgangspunkt i de mere formelle aspekter ved medborgerskabet som rettigheder og pligter. Det konkluderer, at borgere, hvis medborgerskabsrettigheder er garanteret ved loven, er forpligtigede på at efterkomme de krav, som medborgerskabet stiller. ECFR eksemplificerer dette ved at pege på, at eftersom muslimer i Vesten har religionsfrihed, skal de gøre deres borgerlige pligter som for eksempel at indordne sig efter loven. xxiii På trods af, at ECFR har udstukket retningslinjer, der er i konflikt med vestlig lovgivning, er dets holdninger, i hvert fald på det teoretiske niveau, at eftersom muslimer nyder beskyttelse som borgere og har retten til at praktisere islam, er de til gengæld også forpligtede på at overholde loven. Selv om den vestlige lovgivning på nogle område kan stride mod islamiske retsprincipper (som fx islamiske lovprincipper for handel og økonomi), skal lovgivningen overholdes, så længe overholdelsen ikke fører til syndige handlinger, eller får muslimer til at undsige de islamiske trossætninger ('aqîlda). ${ }^{\text {xiv }}$

I relation til emnet medborgerskab beskæftiger ECFR sig også med emnet integration. På rådets årlige møde i 2006 udstedte det generelle retningslinjer for muslimernes måde at leve på i Vesten. ECFR beskriver sig selv som fortalere for en såkaldt positiv integration, der indebærer at,

Muslimer anstrenger sig for at sameksistere [...] på en sådan måde, at det hverken fører til isolation eller assimilation, men en integration hvorigennem, at alle samfundsmedlemmer samarbejder for en fælles fremtid, hvor der tages hensyn til alles interesser med respekt for alle religioner og kulturer. ${ }^{\mathrm{xx}}$

ECFR opfordrer muslimer i Europa til at arbejde for samfundets bedste og udnytte samfundets mange muligheder samtidig med, at de bevarer en muslimsk identitet og efterlever Sharî‘a på en måde, som afspejler islams fleksibilitet. Denne vision om sameksistens i Europa med respekt for en fleksibel religiøs praksis ligger i klar forlængelse af indholdet i størstedelen af ECFR's fatwaer, uanset om emnet er rituel praksis, relation til ikke- 
muslimer, spisevaner eller samfundsmæssigt engagement. ECFR opstiller en række nødvendige forudsætninger for positiv integration rettet mod såvel muslimer som det europæiske samfund. Det stiller krav til de europæiske muslimer om, at 1) lære sproget, kulturen og systemet at kende, 2) bidrage til samfundets bedste og den offentlige interesse og 3) finde et arbejde og blive selvforsørgende. Til gengæld insisterer ECFR på, at de europæiske samfund skal sikre, 1) retfærdighed, lige rettigheder for alle borgere og beskyttelse af religionsfriheden, 2) bekæmpelse af racisme og islamofobi og 3) en styrkelse af interreligiøs dialog og kulturel bevidsthed. ${ }^{\text {xxvi }}$ ECFR har en forventning om, at den såkaldte positive integration vil skabe vejen for øget dialog mellem muslimer og ikke-muslimer og derudover give mulighed for at informere og oplyse ikke-muslimske europæere om islam, hvilket betragtes som en central pligt for muslimer i Vesten.

\section{Konklusion}

FIOE, initiativtagerne bag The European Council for Fatwa and Research, havde en vision om, at fatwarådet med tiden udelukkende ville bestå af europæiske muslimske lærde, som udover de teologiske meritter også havde den nødvendige indsigt i muslimske minoriteters sociale, kulturelle og økonomiske forhold. ECFR's etablering kan dermed ses som en udfordring for traditionelle autoritetsstrukturer blandt muslimske lærde, men ECFR har endnu ikke haft succes med fuldstændigt at frigøre sig fra anerkendte institutioner i den muslimske verden eller autoriteter uddannet herfra. De vestlige fatwaråd opererer inden for en tradition, hvor religiøse institutioner i den muslimske verden altid har fungeret som en fælles referenceramme og som centralt omdrejningspunkt for islamisk tænkning i verden. Ved gradvist at optage flere og flere medlemmer har ECFR bekræftet dette autoritetshierarki frem for at udfordre det.

Analyserne af rådets fatwaer viser, at ECFR's medlemmer i deres religiøse vejledninger tilstræber en tilpasning af den islamiske retsvidenskab og praksis i henhold til de europæiske muslimers forhold. Sammenlignet med fatwaer udstedt af råd fra den muslimske verden kan det konkluderes, at ECFR's fatwaer er mere realistiske med hensyn til hvilke krav, der kan stilles til muslimer i Vesten og er i højre grad tilpasset den vestlige kontekst (Karman 2008:225). ECFR fraråder, at muslimer isolerer sig fra det vestlige majoritets- 
samfund, men opfordrer dem til at deltage aktivt i det politiske og civile liv. ECFR lægger ikke skjul på, at det anser et samfund baseret på islamiske værdier som mest ønskværdigt og anbefaler således muslimer til politisk deltagelse med håbet om, at de med udgangspunkt $\mathrm{i}$ islamiske værdier og gennem oprettelse af muslimske institutioner kan påvirke samfundsudviklingen i, hvad det betragter som, en positiv retning.

Forskrifter, som regulerer udførelsen af en given religiøs handling, forsøger ECFR at tilpasse de vestlige forhold, men de religiøse krav sættes der ikke spørgsmålstegn ved. Som beskrevet tolererer ECFR, at muslimske konvertitter ikke bære tørklæde, men det fastholder, at tørklædet er en religiøs pligt, som alle muslimske kvinder bør efterleve. ECFR's tilpasning af regler vedrørende den religiøse udøvelse fører med andre ord ikke til en reform i islamisk teologi eller retsvidenskab eller til en fornyet hermeneutisk tilgang til de klassiske kilder (Zaman 2002:188). Bassam Tibi har blandt andre præsenteret tesen, at de liberale, demokratiske værdier i Vesten vil skabe grobund for gennemgribende ændringer i muslimsk tænkning og praksis og føre til en ny version af islam med et særligt europæisk, normativt udgangspunkt (Salvatore 2004:1022). Men dette lader ikke til at være den fremherskende tendens i ECFR's vejledninger. Det kan derimod konkluderes, at fatwarådets medlemmer gentager, hvad jurister løbende har gjort gennem islams historie - nemlig at udlede religiøse vejledninger ifølge det diktum, at fatwaer formes og ændres i henhold til den tid og kontekst, de udstedes i. De retslærde balancerer mellem det tidslige og det evige og forsøger at identificere, hvordan islamiske love kan implementeres i praksis i en ikke-muslimsk kontekst. Tilpasningen af regler, som beskriver den religiøse praksis, er ikke på nogen måde udtryk for en omfattende lovmæssig ændring, men snarere udtryk for den islamiske traditions iboende dynamik. Denne dynamik sikrer en fleksibilitet, som er nødvendig for religionens fortsatte relevans. ECFR ønsker at fremme efterlevelsen af islamiske normer blandt muslimer i Vesten og for at garantere, at muslimerne fortsat baserer tilværelsen på islam, er tilpasningen af religiøs praksis til lokale forhold en nødvendighed. 


\section{Litteratur}

Abou El Fadl, Khaled. 1994: "Islamic Law and Muslim Minorities: The Juristic Discourse on Muslim Minorities from the Second/Eighth to the Eleventh/Seventeenth Centuries", Islamic Law and Society, 1(2), 141-187.

Caeiro, Alexandre. 2003: The European Council for Fatwa and Research, paper presented for the Fourth Mediterranean Social and Political Research Meeting, Florence.

- 2004: "The Social Construction of Shar î‘a: Bank Interest, Home Purchase, and Islamic Norms in the West", Die Welt des Islams, 44 (3), 351-375.

Esposito, John. 2002: "The Muslim Diaspora and the Islamic World", in: Shireen T. Hunter, ed., Islam, Europe's Second Religion. The New Social, Cultural, and Political Landscape, Praeger, Westport, 245-255.

DeLorenzo, Yusuf Talal. 2000: "The Fiqh Councilor in North American", in: Yvonne Yazbeck Haddad \& John L. Esposito, eds., Muslims on the Americanization Path? Oxford University Press, New York, 65-86.

Fatwas of the European Council for Fatwa and Research. nd.: Matba' dâr al-nashar alislâmiyya, Cairo.

Harvey, L. P. 1964: "Crypto-Islam in Sixteenth-century Spain”, in: Actas del Primer Congresso de estudios árabes e Islamicos, 163-185.

Hussain, Dilwar. 2004: "Muslim Political Participation in Britain and the Europeanisation of Fiqh", Die Welt des Islams, 44(3), 376-37.

Karman, Karen-Lise Johansen. 2009: "Islamic Law in Europe. The challenge of legal pluralism" in: Lodberg, P, ed., Religion and Normativity. Religion, Politics and Law, Aarhus University Press, Aarhus.

- 2008: Rethinking Islamic Jurisprudence for Muslim Minorities: The Politics and the Work of Contemporary Fatwa Councils, University of Aarhus, Aarhus.

- 2007: "Intellectual Influences between the West and the Muslim World. Religious Authority in Transnational Interaction”, Kvinder, Køn \& Forskning, 2-3, 76-99.

Johansen, Baber. 1993: "Legal Literature and the Problem of Change: The Case of the Land Rent", in: Chibli Mallat, ed., Islam and the Public Law. Classical and Contemporary Studies, Graham and Trotman, London.

Maréchal, Brigitte. 2008: "Universal Aspirations. The Muslim Brotherhood in Europe", in: ISIM Review, nr. 22, 36-37.

Rohe, Mathias. 2004: “The Formation of a European Sharî'a”, in: Jamal Malik, ed., Muslims in Europe. From the Margin to the Centre, LIT Verlag, Münster, 161-184.

Salvatore, Almando.2004: "Making Public Space: Opportunities and Limits of Collective Action among Muslims in Europe", Journal of Ethnic and Migration Studies, nr. 30(5), 1013-1032.

Shadid, W.A.R. \& P.S. van Koningsveld. 1996. "Loyalty to non-Muslim Government. An analysis of Islamic Normative Discussions and of the Views of some Contemporary Islamicists" in: W.A.R. Shadid \& P.S. van Koningsvel, eds., Political Participation and Identities of Muslims in Non-Muslim States, Kok Pharos Publishing House, Kampen, 84-114.

al-Shaybânî, Abu 'Abd Allâh. 1971 ed.: Al-Siyar al-Kabir, Ma'had al-Makhtutat, Cairo. 
Skovgaard-Petersen, Jakob. 1997. Defining Islam for the Egyptian State, Brill, Leiden.Zaman, Muhammad Qasim.2002: The Ulama in Contemporary Islam: Custodians of Change, Princeton studies in Muslim politics, Princeton University Press, Princeton, NJ.

\footnotetext{
${ }^{\mathrm{i}}$ Denne artikel bygger på udvalgte analyser og afsnit fra min ph.d.-afhandling Rethinking Islamic Jurisprudence for Muslim Minorities: The Politics and the Work of Contemporary Fatwa Councils, Aarhus Universitet (2008).

${ }^{i i}$ Upubliceret åbningstale, delvis oversættelse kan findes i Caeiro (2003).

iii Interview med den tidligere præsident for FIOE, Ahmad al- Râwî. Interviewene refereret til i denne artikel blev lavet i forbindelse med ph.d.-afhandling i perioden 2005-2007.

${ }^{\text {iv }}$ Interview med den tidligere præsident for FIOE, Ahmad al-Râwî, Leicester, d. 14. februar 2006.

${ }^{v}$ Fatwas of European Council for Fatwa and Research, engelsk oversættelse af Qarârât wa fatâwâ, Almadjlis al-aurûbbî li al-iftâ (2002).

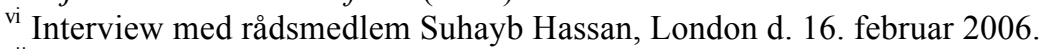

vii Interview med rådsmedlemmerne 'Abdallâh al-Juday', Leeds d. 15. februar 2006 og Sâlim al-Shaykhî, Manchester d. 15. februar 2006.

viii Interview med rådsmedlem 'Abdallâh al-Juday', Leeds d. 15. februar 2006

${ }^{\text {ix }}$ Interview med Suhayb Hassan, London d. 16. februar 2006.

${ }^{\mathrm{x}}$ Fatwa 21, i første fatwasamling, anden del.

${ }^{x i}$ Fatwa 6, første fatwasamling, første del.

xii Final Statement of the first, fourth Ordinary Session of the European Council for Fatwa and Research, 1999.

xiii Final Statement of the second, third and fifteenth Ordinary Session of The European Council for Fatwa and Research, 2005.

${ }^{\text {xiv }}$ Beslutning 1/9, Final Statement, The ninth Ordinary Session of the European Council for Fatwa and Research, 2002.

${ }^{\mathrm{xv}}$ Fatwa 13, første fatwasamling, anden del.

${ }^{x v i}$ Fatwa 2/6, Final Statement, The sixteenth Ordinary Session of the European Council for Fatwa and Research, 2006.

xvii Final Statement, The sixteenth Ordinary Session of the European Council for Fatwa and Research, 2006.

xviii Fatwa 14, første fatwasamling, første del.

${ }^{\text {xix }}$ Fatwa 42, første fatwasamling, første del.

${ }^{x x}$ Beslutning 5/16, Final Statement, The sixteenth Ordinary Session of the European Council for Fatwa and Research, 2006.

xxi Oversættelse fra Koranen i ny dansk overscettelse af Ellen Wulff, 2006.

xxii Beslutning 5/16, Final Statement, The sixteenth Ordinary Session of the European Council for Fatwa and Research, 2006.

xxiii Beslutning 1/16, Final Statement, The sixteenth Ordinary Session of the European Council for Fatwa and Research, 2006.

xxiv Beslutning 2/16 og 3/16, Final Statement, The sixteenth Ordinary Session of the European Council for Fatwa and Research, 2006.

${ }^{x x v}$ Final Statement, The Sixteenth Ordinary Session of the European Council for Fatwa and Research, 2006.

xxvi Analyser præsenteret i Final Statement, The Seventeenth Ordinary Session of the European Council for Fatwa and Research, 2007.
}

\section{Biografisk note:}

Karen-Lise Johansen Karman er ph.d. fra religionsvidenskab på Århus Universitet med afhandlingen "Rethinking Islamic Jurisprudence for Muslim Minorities: The Politics and the Work of Contemporary Fatwa Councils" (2009). Hun er i dag ansat som 
forskningsmedarbejder (specialkonsulent) i Ministeriet for Flygtninge, Indvandrere og Integration. 